\title{
Penaatan dan Penegakan Hukum Lingkungan pada Pembangunan Infrastruktur dalam Mewujudkan Pembangunan Berkelanjutan \\ (Studi Kasus Pembangunan PLTU II di Kecamatan Mundu Kabupaten Cirebon)
}

\author{
Yulinda Adharani* \\ DOI: https://doi.org/10.22304/pjih.v4n1.a4
}

\begin{abstract}
Abstrak
Izin Pemerintah Provinsi Jawa Barat terharap rencana pembangunan PLTU II Kecamatan Astanajapura dan Kecamatan Mundu Kabupaten Cirebon digugat oleh masyarakat sekitar yang terkena dampak langsung ke Pengadilan Tata Usaha Negara. Artikel ini merupakan hasil penelitian terhadap kasus tersebut yang menekankan pada masalah penaatan dan penegakan Hukum Lingkungan dalam mewujudkan pembangunan berkelanjutan, serta upaya penyelesaian sengketa lingkungannya. Penelitian ini menggunakan pendekatan yuridis-normatif dan dianalisa secara kualitatif. Dari hasil penelitian diketahui bahwa pembangunan PLTU di Kecamatan Mundu Kabupaten Cirebon tidak sejalan dengan beberapa tujuan dalam Sustainable Development Goals pada point kesejahteran, pembangunan berkelanjutan, dan pelestarian sumber daya alam. PLTU ini juga tidak sesuai dengan rencana tata ruang, proses penyusunan analisis dampak lingkungan tidak melibatkan masyarakat. Pengadilan mengabulkan gugatan dan memerintahkan pencabutan izin pembangunan tersebut.
\end{abstract}

Kata kunci: hukum lingkungan, pembangunan berkelanjutan, penaatan, penegakan, PLTU.

\section{Environmental Law Compliance and Enforcement on Infrastructure Development to Achieve Sustainable Development (Case Study: Power Plant II Development in Mundu Subdistrict, Cirebon District)}

\begin{abstract}
A lawsuit had been brought to the Administrative Court regarding the Local West Java Province Government Permit on the Power Plant II Development in Astanajapura Subdistrict and Mundu Subdistrict, Cirebon District by the directly affected local community around the power plant location. This article is the research result on the aforementioned lawsuit and will be focusing on the issues surrounding the environmental law compliance and enforcement in achieving sustainable development, as well as the environmental law dispute settlement. This research used the juridical-normative research with qualitative analysis. The article concluded that the Power Plant II development is not in line with several goals as stated in the Sustainable Development Goals; such as the welfare goals, sustainable development, and the natural resources preservation. The Power Plant II is also not in accordance with the local government's spatial plan, and furthermore the local community
\end{abstract}

PADJADJARAN Jurnal Ilmu Hukum Volume 4 Nomor 1 Tahun 2017 [ISSN 2460-1543] [e-ISSN 2442-9325]

* Dosen Fakultas Hukum Universitas Padjadjaran, JI. Dipati Ukur No. 35 Bandung, yulinda.adharani@unpad.ac.id, S.H., M.H. (Universitas Padjadjaran). 
did not take any part during the environmental impact analysis process. According to the Administrative Court Decision, the Court granted the claims in the lawsuit and the permit for the Power Plant II development has been revoked.

Keywords: environmental law, sustainable development, compliance, enforcement, power plant.

\section{A. Pendahuluan}

Pembangunan infrastruktur skala besar menjadi kebutuhan seiring perkembangan masyarakat. Dampak positif dari pembangunan infrastruktur antara lain adalah meningkatnya kesejahteraan rakyat serta pendapatan daerah, namun dampak negatifnya juga tidak sedikit, seperti kelestarian fungsi lingkungan, berkurangnya sumber daya alam akibat eksploitasi yang berlebihan, pencemaran udara akibat polusi industri, dan pembangunan infrastruktur perekonomian yang identik dengan perusakan lingkungan. Dengan demikian, pembangunan infrastruktur skala besar perlu mempertimbangkan konsep pembangunan berkelanjutan untuk meminimalisasi dampak negatifnya.

Jawa Barat menjadi wilayah pembangunan infrastruktur skala besar, hal ini dapat dilihat dari Rencana Pembangunan Jangka Menengah Nasional (RPJMN) dan Peraturan Presiden Nomor 3 Tahun 2015 tentang Proyek Strategis Nasional, yang diperkuat dengan Instruksi Presiden Nomor 1 Tahun 2016 tentang Percepatan Proyek Strategis Nasional. Tercatat sekitar 29 proyek infrastruktur skala besar akan dibangun di wilayah rentan Jawa Barat, ${ }^{1}$ salah satunya ialah pembangunan PLTU.

PLTU Batubara menghasilkan polutan udara terbesar bila dibandingkan dengan sumber energi fosil lainnya, seperti minyak bumi dan gas. Dampak polusi udara PM2.5 dan bahan berbahaya lainnya dari PLTU Batubara tidak dapat diabaikan. Hasil pemodelan atmosfer GEOS-Chem yang dilakukan oleh tim peneliti Harvard University - Atmospheric Chemistry Modeling Group (ACMG) menunjukkan bahwa polusi udara dari operasi PLTU Batubara saat ini telah menyebabkan kematian dini sekitar 6.500 jiwa per tahun. Penyebab utamanya adalah stroke (2.700), penyakit jantung iskemik (2.300), penyakit paru obstruktif kronik (400), kanker paru-paru (300), serta penyakit kardiovaskular dan pernapasan lainnya (800). Selanjutnya, ekspansi PLTU Batubara yang baru di Indonesia akan menyebabkan estimasi angka kematian dini naik menjadi 15.700 jiwa per tahun. $^{2}$

1 Wahana Lingkungan Hidup Indonesia Jawa Barat (Walhi Jabar), “Catatan Akhir Tahun Ruang dan Lingkungan Hidup Jawa Barat 2016: Krisis dan Darurat Bencana Ekologis di Jawa Barat", http://www.walhijabar.org/ 2016/12/29/catatan-akhir-tahun-ruang-dan-lingkungan-hidup-jawa-barat-2016-krisis-dan-darurat-bencanaekologis-di-jawa-barat/, diakses 29 Maret 2017.

2 Greenpeace, Kita, Batubara \& Polusi Udara, Riset Dampak PLTU Batubara oleh Tim Peneliti Universitas Harvard - Atmospheric Chemistry Modeling Group (ACMG) dan Greenpeace Indonesia, Jakarta: Greenpeace Indonesia, 2016, hIm. 10. 
Seperti halnya pembangunan infrasturktur lainnya yang harus melengkapi dokumen Analisis Dampak Lingkungan (AMDAL), PLTU Batubara juga harus melengkapi dokumen tersebut. Dampak dari pembangunan PLTU tersebut, pasti berkonsekuensi pada izin pembangunannya. Demikan yang terjadi pada rencananya pembangunan PLTU II 1X1000 MW akan didirikan di Kecamatan Astanajapura dan Kecamatan Mundu Kabupaten Cirebon. Rencana pembangunan PLTU tersebut telah mendapat izin dengan dikeluarkannya Surat Keputusan Kepala Badan Penanaman Modal dan Perijinan Terpadu Provinsi Jawa Barat Nomor: 660/10/19.1.02.0/BPMPT/2016 tentang Izin Lingkungan Kegiatan Pembangunan dan Operasional PLTU Kapasitas 1×1000 MW di Kecamatan Astanajapura dan Kecamatan Mundu Daerah Kabupaten Cirebon oleh PT Cirebon Energi Prasarana, Tertanggal 11 Mei 2016.

Masyarakat merasa dalam proses penyusunan AMDAL pada izin tersebut tidak terdapat keterlibatan masyarakat yang terkena dampak langsung, selain itu dalam proses permohonan dan proses penerbitannya tidak diumumkan kepada masyarakat yang terkena dampak langsung, sehingga mereka tidak mengetahui kapan penyusunan dokumen AMDAL serta permohonan dan penerbitan izin lingkungan tersebut dilakukan. ${ }^{3}$ Berkenaan dengan hal tersebut Tim Advokasi Hak Atas Keadilan Iklim menggugat Pemerintah Provinsi Jawa Barat ke PTUN Bandung. ${ }^{4}$

Rencana pembangunan PLTU ini juga dianggap akan didirikan di wilayah yang tidak sesuai dengan Rancangan Tata Ruang dan Wilayah (RTRW) Kabupaten Cirebon. Berdasarkan Peraturan Daerah Kabupaten Cirebon Nomor 17 Tahun 2011 tentang RTRW Kabupaten Cirebon Tahun 2011-2031 (Perda RTRW Kab. Cirebon), Kecamatan Mundu bukan wilayah yang diperuntukan untuk PLTU. Dalam Perda tersebut dijelaskan secara eksplisit lokasi/letak pembangunan PLTU yang dikembangkan untuk meningkatkan pasokan listrik jalur transmisi Sumatera-JawaBali berada di Kecamatan Astanajapura. ${ }^{5}$ Artinya secara limitatif lokasi pembangunan PLTU dalam struktur ruang ada di Kecamatan Astanajapura. Kecamatan Mundu hanya perlintasan jaringan transmisi listrik berupa Saluran Udara Tegangan Tinggi (SUTT). ${ }^{6}$

Artikel ini merupakan hasil penelitian terhadap kasus pembangunan PLTU II di Kecamatan Mundu yang menekankan pada masalah penaatan dan penegakan Hukum Lingkungan dalam mewujudkan pembangunan berkelanjutan, serta upaya

3 Lihat Bagian C dalam Pokok Perkara Bekas Perkara Pengadilan Tata Usaha Negara Bandung No. 124/G/LH/2016/PTUN.BDG terkait Pencemaran Udaha dan Gangguan (Kebisingan, Getaran, dan Kebauan) yang didaftarkan di PTUN Bandung pada hari Selasa, 6 Desember 2016.

4 Berkas perkara Nomor 124/G/LH/2016/PTUN.BDG terkait Pencemaran Udaha dan Gangguan (Kebisingan, Getaran, dan Kebauan) yang didaftarkan di PTUN Bandung pada hari Selasa, 6 Desember 2016.

$5 \quad$ Pasal 19 ayat (4) huruf a Peraturan Daerah Kabupaten Cirebon Nomor 17 Tahun 2011 tentang Rencana Tata Ruang Wilayah Kabupaten Cirebon Tahun 2011-2031 (Perda Kabupaten Cirebon 17/2011)

6 Pasal 19 ayat (5) huruf b Perda Kabupaten Cirebon 17/2011. 
penyelesaian sengketa lingkungannya. Hasil penelitian ini diharapkan dapat menjadi bahan masukan bagi pemangku kepentingan dalam merumuskan kebijakan-kebijakan dalam penaatan dan penegakan hukum lingkungan guna mewujudkan pembangunan berkelanjutan.

\section{B. Metode Penelitian}

Penelitian ini menggunakan pendekatan yuridis-normatif dalam arti menggunakan data kepustakaan/sekunder (baik berupa bahan hukum primer, bahan hukum sekunder maupun bahan hukum tersier) sebagai bahan utama penelitian. Metode penelitian yang bersifat deskriptif analitis dengan pendekatan sistemik. Sistem berarti suatu kesatuan yang tersusun secara teratur rapi atas bagian-bagian berikut perinciannya sedemikian rupa hingga dapat mencapai tujuan yang sudah pasti. ${ }^{7}$

Analisis yuridis-kualitatif digunakan dengan mengandalkan pada kemampuan abstraksi-teoritis atas bahan-bahan hukum di atas, dengan menggunakan metode penafsiran hukum dan konstruksi hukum, terutama penafsiran sistematis dan penafsiran sosiologis atas peraturan perundang-undangan terkait materi kajian. Pengumpulan data dilakukan dengan studi kepustakaan dan studi lapangan. Data kepustakaan diperoleh dari perpustakaan perguruan tinggi yang diperkirakan memiliki kompetensi di bidang yang terkait dengan materi penelitian termasuk pada instansi atau lembaga-lembaga penelitian dan lembaga negara yang terkait dengan materi penelitian. Pengumpulan informasi dilakukan dengan menggunakan metode wawancara dengan narasumber yang ditentukan secara purposif (judgemental). Wawancara dilakukan secara terarah dengan menggunakan pedoman wawancara yang telah disusun sebagai arahannya.

\section{Pembahasan}

\section{Pembangunan Berkelanjutan}

Pembangunan berkelanjutan dipopulerkan melalui laporan Komisi Dunia tentang Lingkungan dan Pembangunan pada tahun 1987. Perspektif keberlanjutan diartikan sebagai kapasitas pembaruan dan evolusi dalam ekosistem, serta inovasi dan kreativitas dalam sistem sosial. ${ }^{8}$ Konsep ini muncul dari kesepakatan bersama antara anggota komisi, bahwa banyak kegiatan pembangunan yang mengakibatkan kemiskinan dan kemerosotan serta kerusakan lingkungan, sehingga perlu ditempuh jalan baru bagi pembangunan yang membawa kemajuan bagi manusia tidak hanya untuk sementara waktu melainkan untuk jangka waktu yang lebih panjang. ${ }^{9}$

7 Munadjat Danusaputro, Hukum Lingkungan, Buku 1: Umum, Bandung: Binacipta, 1980, hlm. 7.

8 Bandingkan dengan Bruce Mitchell (et.al.), Pengelolaan Sumber daya dan Lingkungan, Yogyakarta: Gadjah Mada University Press, 2000, hlm. 33.

$9 \quad$ Ibid., hlm. 32. 
Dua konsep kunci yang jarang dikutip adalah bahwa pembangunan berkelanjutan berkaitan dengan pertama, kebutuhan manusia di negara berkembang untuk memenuhi kebutuhannya dan kedua, keterbatasan teknologi dan organisasi sosial yang berkaitan dengan kapasitas lingkungan untuk mencukupi kebutuhan generasi sekarang dan masa depan. ${ }^{10} \mathrm{Hal}$ ini menyebabkan perbedaan penekanan dalam penerapan pembangunan berkelanjutan di negara maju dan negara berkembang. Negara berkembang memberikan prioritas pembangunan berkelanjutan pada pemenuhan kebutuhan dasar manusia saat ini, serta menjamin kelangsungan pembangunan ekonomi. ${ }^{11}$ Penekanan ini menempatkan keterpaduan pertimbangan ekonomi dan lingkungan sebagai strategi pembangunan berkelanjutan.

Prinsip keberlanjutan (sustainability development) didefinisikan sebagaimana disebut dalam 'The Brundtland Report' sebagai berikut:" "Sustainable development is development that meet the need of the present whitout compromising the ability of future generations meet their own needs". Definisi ini mengandung 2 (dua) konsep kunci, yaitu:

a. The concept of needs, in particular the essential need of the world's poor, to which overriding priority should be given; and

b. The idea of limitation imposed by the state of technology and social organization on the environment's ability to meet present and future needs.

Menurut Surna T Djajadiningrat, yang dimaksud dengan pembangunan berkelanjutan adalah pembangunan yang dapat memenuhi kebutuhan saat ini dengan mengindahkan kemampuan generasi mendatang dalam mencukupi kebutuhannya. Beliau juga mengatakan bahwa proses pembangunan berkelanjutan bertumpu pada 3 (tiga) faktor, yaitu:

a. Kondisi sumber daya alam;

b. Kualitas lingkungan; dan

c. Faktor kependudukan.

Ketiga faktor di atas mengingatkan bahwa pembangunan berkelanjutan perlu memuat ikhtiar untuk memelihara keutuhan fungsi tatanan lingkungan agar sumber daya alam dapat secara berlanjut menopang proses pembangunan secara terus menerus dari generasi ke generasi untuk meningkatkan kualitas manusia Indonesia. ${ }^{13}$

10 Ibid.

$11 \quad$ Ibid., hlm 46

12 M Daud Silalahi, "Perkembangan Hukum Lingkungan dalam Perkembangan Internasional dan Nasional: Ditinjau dari Perpektif Ilmu Lingkungan dalam Pembangunan Berkelanjutan", Makalah disampaikan dalam Perkembangan Hukum Lingkungan Kini dan Masa Depan, Prosiding Seminar Nasional \& Kongres Pembina Hukum Lingkungan se - Indonesia, 2013, hlm. 9-10.

13 Surna T. Djajadiningrat, "Pembangunan Berkelanjutan dan Berwawasan Lingkungan", Jurnal Hukum Lingkungan, Indonesian Center for Environmental Law, Tahun 1, No. 1,1994, hlm. 6-9. 
Sidang umum Perserikatan Bangsa-Bangsa (PBB) yang berlangsung 25 September 2015 di New York, Amerika Serikat secara resmi telah menetapkan Agenda Pembangunan Berkelanjutan atau Sustainable Development Goals (SDGs) sebagai kesepakatan pembangunan global. Sekurangnya 193 kepala negara hadir, mengesahkan Agenda Pembangunan Berkelanjutan 2030. Mulai tahun 2016, SDGs 2015-2030 secara resmi menggantikan Tujuan Pembangunan Millennium/ Millenium Development Goals (MDGs) 2000-2015. SDGs berisi seperangkat tujuan transformatif yang disepakati dan berlaku bagi seluruh bangsa tanpa terkecuali. SDGs berisi 17 tujuan dan salah satu tujuan SDGs adalah mengatur tata cara dan prosedur masyarakat yang damai tanpa kekerasan, nondiskriminasi, partisipasi, tata pemerintahan yang terbuka serta kerja sama kemitraan multi pihak. ${ }^{14}$

\section{Gambar 1. Agenda Pembangunan Berkelanjutan 2030 (Sustainable Development Goals 2030)}
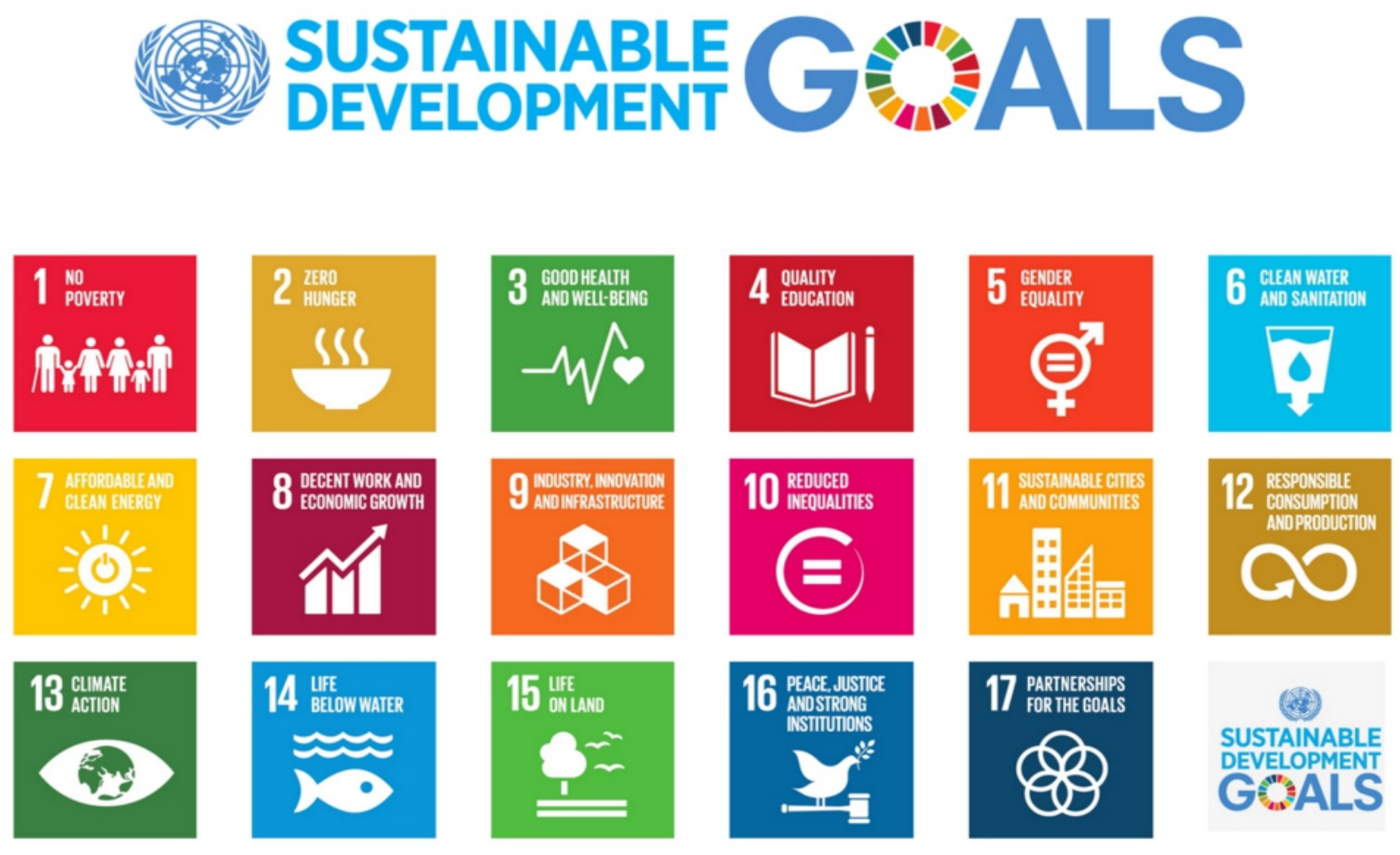

Sumber: PBB

SDGs diusulkan untuk menawarkan perbaikan besar MDGs. Perbaikan tersebut berupa usulan untuk membangun MDGs dan menyelesaikan apa yang belum dicapai. Selain itu, SDGs berusaha untuk mewujudkan hak asasi manusia dan untuk

14 Perserikatan Bangsa-Bangsa (PBB), "Sustainable Development Knowledge Platform", https://sustainabledevelopment.un.org/sdgs, diakses 29 Maret 2017 
mencapai kesetaraan gender dan pemberdayaan semua perempuan dan anak perempuan. Hal ini terintegrasi, tak terpisahkan dan seimbang dengan tiga dimensi pembangunan berkelanjutan: ekonomi, sosial, dan lingkungan. PBB mengumumkan 17 tujuan pembangunan berkelanjutan dan 169 target yang menunjukkan skala dan ambisi agenda secara universal. Tujuan dan target tersebut akan dilaksanakan selama 15 tahun ke depan di daerah-daerah penting untuk kemanusiaan dan planet. Tujuh belas tujuan pembangunan berkelanjutan antara lain: ${ }^{15}$

1. Mengakhiri kemiskinan di semua tempat dalam bentuk apapun;

2. Mengakhiri kelaparan, mencapai ketahanan pangan, dan peningkatan gizi dan mempromosikan pertanian berkelanjutan;

3. Menjamin kehidupan yang sehat serta mendorong kesejahteraan hidup untuk seluruh masyarakat di segala umur;

4. Memastikan pendidikan berkualitas yang inklusif dan berkeadilan dan mempromosikan kesempatan belajar seumur hidup bagi semua;

5. Pencapaian kesetaraan gender dan memberdayakan semua wanita dan perempuan;

6. Memastikan ketersediaan dan pengelolaan air dan sanitasi yang berkelanjutan bagi semua;

7. Memastikan akses energi yang terjangkau, handal, berkelanjutan, dan modern untuk semua;

8. Mempromosikan pertumbuhan yang berkelanjutan, inklusif dan keberkelanjutan ekonomi, tenaga yang produktif, dan pekerjaan yang layak bagi semua;

9. Membangun infrastruktur tangguh, mempromosikan industrialisasi yang inklusif and berkelanjutan, dan membantu pengembangan inovasi;

10. Mengurangi ketidaksetaraan dalam dan antar negara;

11. Membuat kota dan pemukiman inklusif, aman, tangguh, dan berkelanjutan;

12. Memastikan pola konsumsi dan produksi berkelanjutan;

13. Tindakan mendesak untuk memerangi perubahan iklim dan dampaknya;

14. Melestarikan penggunaan sumber daya laut untuk pembangunan berkelanjutan;

15. Melindungi, memulihkan, dan mempromosikan pemanfaatan berkelanjutan dari ekosistem, pengelolaan hutan, memerangi degradasi, dan menghentikan degradasi lahan, serta menghentikan hilangnya keanekaragaman hayati;

16. Mempromosikan masyarakat yang damai dan inklusif untuk pembangunan berkelanjutan, memberikan akses keadilan bagi semua dan membangun

15 United Nations Development Programme (UNDP) Indonesia, "Agenda Pembangunan Berkelanjutan 2030", http://www.id.undp.org/content/indonesia/id/home/post-2015/sdg-overview/, diakses 29 Maret 2017 
institusi akuntabel dan inklusif yang efektif; dan

17. Memperkuat sarana implementasi dan merevitalisasi kemitraan global untuk pembangunan berkelanjutan.

Apabila dilihat kasus pembangunan PLTU II di Cirebon ini, ada beberapa aspek yang tidak sejalan dengan tujuan dari 17 agenda yang direncanakan, yaitu:

1. Tujuan 1, mengakhiri kemiskinan di semua tempat dalam bentuk apapun (no poverty). Apabila warga di daerah terkena dampak yang kebanyakan adalah nelayan terancam tidak mempunyai akses atau berkurangnya hasil tangkapan mereka, maka kemiskinan akan tetap banyak terjadi khususnya di Kabupaten Cirebon.

2. Tujuan 9, membangun infrastruktur tangguh, mempromosikan industrialisasi yang inklusif dan berkelanjutan dan membantu pengembangan inovasi (Industry, Innovation and Infrastructure). Pembangunan PLTU II ini merupakan program strategis nasional untuk pembangunan infrastruktur, apabila tidak memperhatikan keberlanjutan maka tujuan untuk membangun infrastruktur tangguh yang inklusif dan berkelanjutan ini tidak akan tercapai.

3. Tujuan 14, melestarikan penggunaan sumber daya laut untuk pembangunan berkelanjutan.

Masalah lingkungan di negara yang sedang berkembang seperti Indonesia berbeda dengan masalah lingkungan di negara maju atau industri. Masalah lingkungan di negara maju disebabkan oleh pencemaran sebagai akibat sampingan yang menggunakan banyak energi, teknologi maju yang boros energi pada industri, kegiatan transportasi, dan komunikasi serta kegiatan-kegiatan ekonomi lainnya. Masalah lingkungan di Indonesia terutama berakar pada keterbelakangan pembangunan. Karena itu, apabila negara industri mempunyai pandangan yang kuat untuk mengatasi masalah lingkungan dengan tidak meningkatkan pembangunan, lazim dikenal dengan pertumbuhan nol (zero growth), bagi Indonesia justru untuk mengatasi masalah lingkungan diperlukan pertumbuhan ekonomi dengan meningkatkan pembangunan nasional. ${ }^{16}$

\section{Penaatan dan Penegakan Hukum Lingkungan}

Penegakkan hukum lingkungan dimulai dengan penaatan hukum lingkungan. Penaatan dalam hukum lingkungan diartikan sebagai "penerapan sepenuhnya persyaratan lingkungan. Penaatan dapat dikatakan tercapai apabila semua persyaratan lingkungan terpenuhi atau terlaksana oleh subjek hukum lingkungan". ${ }^{17}$

16 Daud Silalahi, Hukum Lingkungan dalam Sistem Penegakan Hukum Lingkungan Indonesia, Bandung: Alumni, 2001, hlm. 18.

17 Sukanda Husin, Penegakan Hukum Lingkungan Indonesia, Cetakan Kedua, Jakarta: Sinar Grafika, 2009, hlm.139 
Perancangan persyaratan lingkungan menjadi sangat signifikan dalam penaatan hukum lingkungan karena persyaratan lingkungan mempengaruhi keberhasilan program pengelolaan lingkungan. Perancangan persyaratan lingkungan yang baik untuk menghasilkan penaatan yang efektif dan efisien dapat dilakukan dengan beberapa pendekatan, antara lain: pendekatan 'atur' dan 'awasi', pendekatan atur diri sendiri, pendekatan ekonomi, pendekatan perilaku, dan pendekatan tekanan publik.

Proses penegakan hukum sendiri meliputi penaatan, penindakan, dan penyelesaian sengketa. Penaatan (compliance) merupakan suatu proses untuk memotivasi masyarakat melaksanakan hukum secara sukarela. Bila dikaitkan dengan kesadaran hukum masyarakat, proses tersebut harus memperhatikan pengetahuan, pemahaman dan perilaku masyarakat terhadap hukum. Selain itu, penaatan bersifat preventif sedangkan penindakan bersifat represif dan dalam sistem hukum lingkungan nasional, proses penindakan meliputi proses penanggulangan, pengendalian, penerapan sanksi administratif, dan rehabilitasi.

Penyelesaian sengketa merupakan bagian dari proses penegakan hukum, karena pada dasarnya penyelesaian sengketa merupakan proses yang harus ditempuh sebagaimana diperintahkan oleh hukum, sebagai konsekuensi terjadinya pelanggaran hukum. ${ }^{18}$ Dengan demikian, penegakan hukum lingkungan merupakan upaya untuk mencapai ketaatan terhadap peraturan dan persyaratan dalam ketentuan hukum lingkungan yang berlaku secara umum dan individual, melalui pengawasan dan penerapan sanksi administrasi, kepidanaan, dan keperdataan.

Instrumen pencegahan pencemaran dan/atau kerusakan lingkungan hidup (penaatan hukum lingkungan) terdiri atas: ${ }^{19}$
a. Kajian Lingkungan Hidup Strategis (KLHS);
b. tata ruang;
c. baku mutu lingkungan hidup;
d. kriteria baku kerusakan lingkungan hidup
e. AMDAL;
f. Upaya Pengelolaan Lingkungan Hidup dan Upaya Pemantauan Lingkungan Hidup (UKL-UPL);
g. perizinan;
h. instrumen ekonomi lingkungan hidup;
i. peraturan perundang-undangan berbasis lingkungan hidup;
j. anggaran berbasis lingkungan hidup;
k. analisis risiko lingkungan hidup;

18 Imamulhadi, Hukum Lingkungan Alternatif; Hukum Lingkungan Adat dan Hukum Lingkungan Islam, Yogyakarta: K-Media, 2016, hlm. 130-147.

19 Pasal 14 Undang-Undang Nomor 32 Tahun 2009 tentang Perlindungan dan Pengelolaan Lingkungan Hidup (UU PPLH). 
I. audit lingkungan hidup; dan

m. instrumen lain sesuai dengan kebutuhan dan/atau perkembangan ilmu pengetahuan.

Ruang sebagai sumber daya pada dasarnya tidak mengenal batas wilayah. Namun untuk mewujudkan ruang wilayah nasional yang aman, nyaman, produktif, dan berkelanjutan berlandaskan Wawasan Nusantara dan Ketahanan Nasional, serta sejalan dengan kebijakan otonomi daerah yang nyata, luas, dan bertanggung jawab, maka penataan ruang menuntut kejelasan pendekatan dalam proses perencanaannya demi menjaga keselarasan, keserasian, keseimbangan, dan keterpaduan antardaerah, antara pusat dan daerah, antarsektor, dan antar pemangku kepentingan.

Dalam Undang-Undang Nomor 26 Tahun 2007 tentang Penataan Ruang (UU Penataan Ruang), penataan ruang didasarkan pada pendekatan sistem, fungsi utama kawasan, wilayah administratif, kegiatan kawasan dan nilai strategis kawasan. Berkaitan dengan kebijakan otonomi daerah tersebut, wewenang penyelenggaraan penataan ruang oleh pemerintah dan pemerintah daerah, yang mencakup kegiatan pengaturan, pembinaan, pelaksanaan, dan pengawasan penataan ruang, didasarkan pada pendekatan wilayah dengan batasan wilayah administratif. Dengan pendekatan wilayah administratif tersebut, penataan ruang seluruh wilayah Indonesia terdiri atas wilayah nasional, wilayah provinsi, wilayah kabupaten, dan wilayah kota, yang setiap wilayah tersebut merupakan subsistem ruang menurut batasan administratif. Di dalam subsistem tersebut terdapat sumber daya manusia dengan berbagai macam kegiatan pemanfaatan sumber daya alam dan sumber daya buatan, serta dengan tingkat pemanfaatan ruang yang berbedabeda sehingga apabila tidak ditata dengan baik dapat mendorong ke arah adanya ketidakseimbangan pembangunan antarwilayah serta ketidaksinambungan pemanfaatan ruang.

Penataan ruang sebagai suatu sistem perencanaan tata ruang, pemanfaatan ruang, dan pengendalian pemanfaatan ruang merupakan satu kesatuan yang tidak terpisahkan antara yang satu dan yang lain dan harus dilakukan sesuai dengan kaidah penataan ruang sehingga diharapkan dapat mewujudkan pemanfaatan ruang yang berhasil guna dan berdaya guna serta mampu mendukung pengelolaan lingkungan hidup yang berkelanjutan; tidak terjadi pemborosan pemanfaatan ruang; dan tidak menyebabkan terjadinya penurunan kualitas ruang. Penataan ruang yang didasarkan pada karakteristik, daya dukung dan daya tamping lingkungan, serta didukung oleh teknologi yang sesuai akan meningkatkan keserasian, keselarasan, dan keseimbangan subsistem. Hal itu berarti akan dapat meningkatkan kualitas ruang yang ada.

Selain itu, pengelolaan subsistem yang satu berpengaruh pada subsistem yang lain dan pada akhirnya dapat mempengaruhi sistem wilayah ruang nasional secara 
keseluruhan, maka pengaturan penataan ruang perlu mengembangkan suatu sistem keterpaduan sebagai ciri utama. Hal ini berarti diperlukan adanya suatu kebijakan nasional tentang penataan ruang yang dapat memadukan berbagai kebijakan pemanfaatan ruang. Seiring dengan maksud tersebut, pelaksanaan pembangunan yang dilaksanakan baik oleh pemerintah, pemerintah daerah, maupun masyarakat, pada tingkat pusat maupun daerah, harus dilakukan sesuai dengan rencana tata ruang yang telah ditetapkan. Perlindungan dan pengendalian fungsi lingkungan hidup disusun dengan penataan ruang yang terdiri dari tiga kegiatan utama, yaitu: perencanaan tata ruang, perwujudan tata ruang, dan pengendalian tata ruang. ${ }^{20}$

Pemerintah Indonesia saat ini telah menetapkan RPJPN 2005-2025 dalam bentuk undang-undang RPJPN. Undang-Undang inilah yang dijadikan sebagai dokumen hukum untuk perencanaan pembangunan periode 20 tahun baik di tingkat pusat maupun di tingkat daerah (provinsi dan kabupaten/kota). Oleh karena itu, pemerintah daerah dalam melakukan penyusunan Rencana Pembangunan Jangka Panjang Daerah (RPJPD) wajib mengacu kepada RPJP Nasional ini sebagai satu kesatuan sistem. ${ }^{21}$

Program Pembangunan Nasional dilaksanakan sesuai dengan RPJP Nasional 2005-2025 dan Program Pembangunan Daerah dilaksanakan sesuai dengan RPJP Daerah 2005-2025, dengan demikian RPJP Daerah 2005-2025 juga disesuaikan dengan RPJP Nasional 2005-2025. ${ }^{22}$ Rincian program pembangunan nasional dan program pembangunan daerah sebagaimana dimaksud meliputi: bidang sosial budaya dan kehidupan beragama, ekonomi, ilmu pengetahuan dan teknologi, politik, pertahanan dan keamanan, hukum dan aparatur, pembangunan wilayah dan tata ruang, penyediaan sarana dan prasarana, serta pengelolaan sumber daya alam (SDA) dan lingkungan hidup. ${ }^{23}$

Pembangunan daerah sebagaimana disebutkan di atas merupakan bagian integral dari pembangunan nasional. Pembangunan nasional dan pembangunan daerah yang telah dilaksanakan di satu sisi telah menunjukkan kemajuan di berbagai bidang kehidupan masyarakat. Namun di sisi lain, ketersediaan SDA secara kuantitas ataupun kualitas tidak merata, sedangkan kegiatan pembangunan membutuhkan SDA yang semakin meningkat. Sementara itu, kegiatan pembangunan yang dilakukan juga mengandung risiko terjadinya pencemaran dan kerusakan lingkungan. Kondisi ini dapat mengakibatkan daya dukung, daya tampung, dan produktivitas lingkungan hidup menurun serta pada akhirnya menjadi per-

\footnotetext{
20 Lihat Penjelasan Undang-Undang Nomor 26 Tahun 2007 tentang Penataan Ruang.

21 Lihat Undang-Undang Nomor 17 Tahun 2007 tentang Rencana Pembangunan Jangka Panjang Nasional 20052025.

22 Ibid.

23 Ibid.
} 
masalahan termasuk dampak pembangunan terhadap manusia dan makhluk hidup lainnya.

Terkait dengan adanya penyesuaian penataan ruang di Kabupaten Cirebon, dalam penyusunannya RTRW Kabupaten Cirebon sudah mengacu pada Kajian Lingkungan Hidup Strategis (KLHS) Ciayumajakuning-Gardang. Hal ini sebagaimana diamanatkan dalam Undang-Undang Nomor 32 Tahun 2009 tentang Perlindungan dan Pengelolaan Lingkungan Hidup (UU PPLH) bahwa RTRW harus mengacu pada KLHS. Perumusan substansi RTRW yang memuat tujuan, kebijakan dan strategi, rencana, arahan pemanfaatan dan pengendalian, ditujukan untuk dapat menjaga sinkronisasi dan konsistensi pelaksanaan penataan ruang serta mengurangi penyimpangan implementasi indikasi program utama yang ditetapkan yang diharapkan akan lebih mampu merespon tantangan dan menjamin keberlanjutan pembangunan melalui berbagai pembenahan serta pembangunan ruang yang produktif dan berdaya saing tinggi, demi terwujudnya masyarakat yang lebih sejahtera. ${ }^{24}$

Berdasarkan dokumen AMDAL, PLTU dengan kapasitas 1X1000 MW akan didirikan di Kabupaten Cirebon tepatnya di Kecamatan Astanajapura dan Kecamatan Mundu. Kedua kecamatan tersebut merupakan kecamatan yang berada di Kabupaten Cirebon, sehingga pengaturan pola dan struktur ruang dua kecamatan tersebut menjadi kewenangan Pemerintah Kabupaten Cirebon dan sudah diatur dengan jelas oleh Perda RTRW Kab. Cirebon. Penataan ruang dalam peraturan daerah tersebut adalah proses perencanaan tata ruang baik dalam wujud struktur dan pola yang guna mengatur pemanfaatan dan pengendalian ruang. Sehingga setiap pemerintah daerah mempunyai kebijakan melakukan penataan ruang untuk mewujudkan pembangunan yang berkelanjutan. ${ }^{25}$

24 Lihat Penjelasan Perda Kabupaten Cirebon 17/2011.

25 Lihat Bagian C dalam Pokok Perkara Bekas Perkara Pengadilan Tata Usaha Negara Bandung No. 124/G/LH/2016/PTUN.BDG terkait Pencemaran Udaha dan Gangguan (Kebisingan, Getaran, dan Kebauan) yang didaftarkan di PTUN Bandung pada hari Selasa, 6 Desember 2016. 


\section{Gambar 2. Peta Kawasan Kabupaten Cirebon}

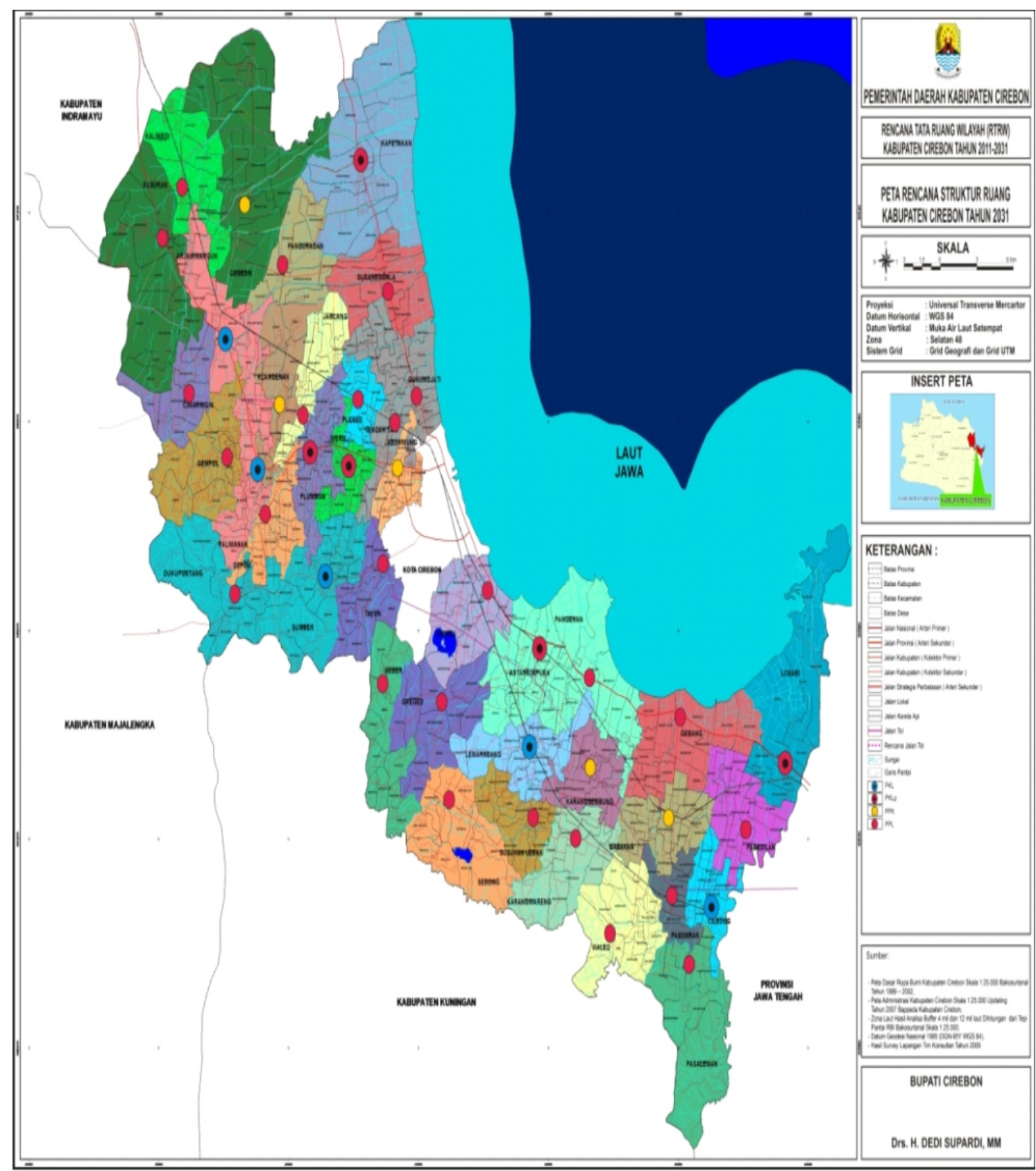

Sumber: Badan Perencanaan Pembangunan Daerah (Bappeda) Kabupaten Cirebon

Kabupaten Cirebon berada di daerah pesisir Laut Jawa Dan berdasarkan letak geografisnya, wilayah Kabupaten Cirebon berada pada posisi $6^{\circ} 30^{\prime}-7^{\circ} 00^{\prime}$ Lintang Selatan dan $108^{\circ} 40^{\prime}-108^{\circ} 48^{\prime}$ Bujur Timur. Bagian utara merupakan dataran rendah, sedang bagian barat daya berupa pegunungan, yakni Lereng Gunung Ciremei. Letak daratannya memanjang dari barat laut ke tenggara. Tujuan yang ditetapkan 
pemerintah daerah kabupaten yang merupakan arahan perwujudan visi dan misi pembangunan jangka panjang kabupaten pada aspek keruangan, yang pada dasarnya mendukung terwujudnya ruang wilayah nasional yang aman, nyaman, produktif, dan berkelanjutan berlandaskan nusantara dan ketahanan nasional. ${ }^{26}$

Dalam Perda RTRW Kab. Cirebon dijelaskan secara eksplisit lokasi/letak pembangunan PLTU yang dikembangkan untuk meningkatkan pasokan listrik jalur transmisi Sumatera-Jawa-Bali berada di Kecamatan Astanajapura. ${ }^{27}$ Peruntukan wilayah Kecamatan Mundu sesuai dengan Perda adalah adalah sebagai berikut:

1. Kecamatan Mundu diperuntukan untuk sistem perdesaan;

2. Kecamatan Mundu diperuntukan untuk sistem perkotaan khususnya peranan PKL Lemahabang;

3. Kecamatan Mundu diperuntukan untuk perlintasan jalur kereta api Cirebon-Semarang;

4. Kecamatan Mundu diperuntukan untuk perlintasan jalur kereta api Cirebon-Yogyakarta;

5. Kecamatan Mundu diperuntukan untuk rencana pengambangan stasiun kereta api Stasiun Luwung dan Satsiun Waruduwur;

6. Kecamatan Mundu diperuntukan untuk lintasan jaringan transmisi listrik meliputi SUTT;

7. Kecamatan Mundu diperuntukan untuk pelestarian dan pemanfaatan situ Patok untuk irigasi dan pariwisata;

8. Kecamatan Mundu diperuntukan untuk jalur evakuasi bencana alam gelombang pasang dan abrasi dan banjir;

9. Kecamatan Mundu diperuntukan untuk kawasan resapan air, khususnya di Desa Sinarancang seluas 4 (empat) hektar;

10. Kecamatan Mundu diperuntukan untuk pertanian Hortikultura sayuran seluas 5000 hektar;

11. Kecamatan Mundu diperuntukkan untuk pertenakan besar seluas 10 (sepuluh) hektar;

12. Kecamatan Mundu diperuntukan untuk perikanan budidaya air tawar, perikanan budidaya air laut, perikanan budidaya air tambak, untuk industri pengolahan perikanan, untuk pelabuhan pendaratan;

13. Kecamatan Mundu diperuntukan untuk industri besar berupa industri manufaktur; dan

14. Kecamatan Mundu diperuntukan untuk industri soun.

Dalam Perda RTRW Kab. Cirebon tidak ada pasal yang menyebutkan dengan jelas bahwa Kecamatan Mundu Kabupaten Cirebon diperuntukan sebagai PLTU

26 Pasal 1 ayat (23) Perda Kabupaten Cirebon 17/2011.

27 Pasal 19 ayat (4) huruf a Perda Kabupaten Cirebon 17/2011. 
1X1000 MW, baik dari struktur dan maupun dari pola ruang. Sangat jelas dan eksplisit bahwa pembangunan PLTU hanya diperbolehkan di Kecamatan Astanajapura. Lampiran Peraturan Menteri Lingkungan Hidup Nomor 8 Tahun 2013 tentang Tata Laksana Penilaian dan Pemeriksaan Dokumen Lingkungan Hidup serta Penerbitan Izin Lingkungan secara jelas membatasi pembahasan dokumen AMDAL tidak boleh bertentangan dengan RTRW kabupaten/kota. Jika dalam pembahasan ditemukan adanya pertentangan dengan RTRW maka penyusunan dan pembahasan haruslah ditolak.

Selain itu, dalam dokumen ANDAL 1-7 juga terdapat ketidaksesuaian tentang luas ruang lingkup AMDAL. Apakah ruang lingkup dalam AMDAL tersebut seluas 40,03 Ha atau seluas 204,3 Ha karena di dalam ANDAL 1-7 menyebutkan: ${ }^{28}$

"Dari total luas lahan tersebut, kebutuhan lahan untuk pembangunan PLTU Cirebon kapasitas 1 X 1000 MW termasuk sarana dan prasarananya diperkirakan hanya mencapai $\pm 40,03 \mathrm{Ha}$. Dengan demikian terdapat sisa lahan yang tidak dibangun untuk PLTU kapasitas 1X1000 MW seluas $\pm 164,27 \mathrm{Ha}$. Lahan tersebut diperuntukan untuk pengembangan PLTU Cirebon ekspansi unit-unit berikutnya di masa akan datang. Komposisi perolehan lahan seluas 204,3 Ha berdasarkan wilayah administrasi Desa disajikan pada table 1-3 dan komposisi lahan untuk pembangunan PLTU 1X1000 MW berdasarkan wilayah administrasi desa disajikan pada table 1-4."

Apabila dilihat baku mutu lingkungan, kualitas udara ambient di sekitar lokasi PLTU, telah menunjukkan level yang mengkhawatirkan dibandingkan dengan baku mutu ambient. Terutama konsentrasi PM 2,5 di beberapa titik pengujian yang berdekatan dengan pemukiman, yaitu: ${ }^{29}$

a. kode lokasi AQN-02, di Desa Astanamukti, Kec. Pangenan, yang menunjukkan angka 45,39 dari baku mutu udara ambien nasional (BMUA) $65 \mu \mathrm{g} / \mathrm{m} 3$;

b. kode lokasi AQN-03, di Desa Astanamukti, Kec. Pangenan, yang menunjukkan angka 50,56 $\mathrm{gg} / \mathrm{m} 3$ dari baku mutu udara ambien nasional (BMUA) $65 \mu \mathrm{g} / \mathrm{m3}$; dan

c. kode lokasi AQN-06, di Desa Kanci Kulon, Kec. Astanajapura, yang menunjukkan angka 41,25 $\mathrm{\mu g} / \mathrm{m} 3$ dari baku mutu udara ambien nasional (BMUA) $65 \mu \mathrm{g} / \mathrm{m3}$.

\footnotetext{
28 Lihat Bagian C dalam Pokok Perkara Bekas Perkara Pengadilan Tata Usaha Negara Bandung No. 124/G/LH/2016/PTUN.BDG terkait Pencemaran Udaha dan Gangguan (Kebisingan, Getaran, dan Kebauan) yang didaftarkan di PTUN Bandung pada hari Selasa, 6 Desember 2016. 
Lebih jauh, hasil pengujian kualitas udara ambient di sekitar lokasi pembangunan PLTU dapat dilihat dalam grafik berikut:

\section{Gambar 3. Baku Mutu Lingkungan (Kualitas udara ambient)}
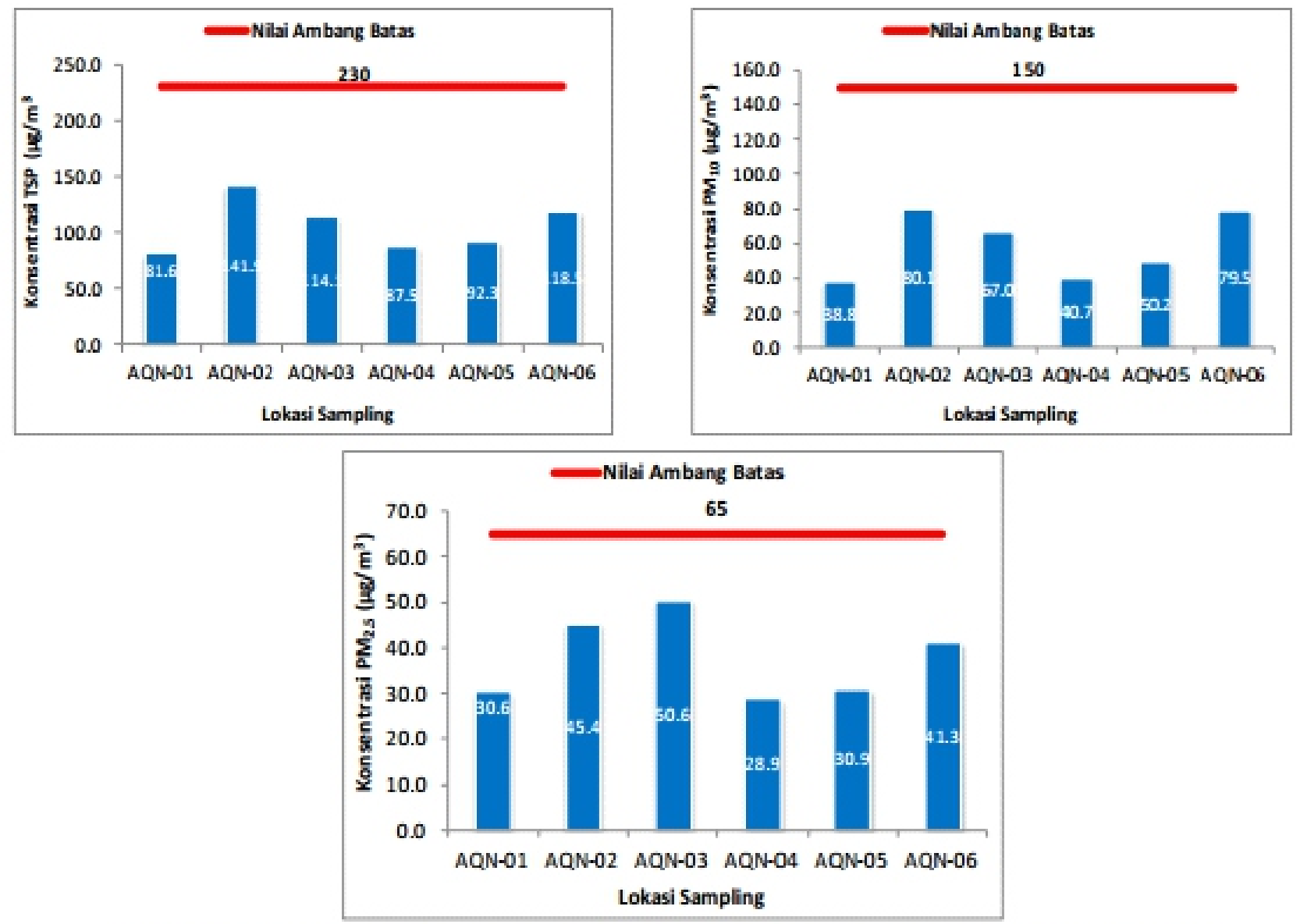

\section{Gambar 2-7 Konsentrasi partikulat (TSP, $\mathrm{PM}_{10}$ dan $\mathrm{PM}_{2,5}$ ) di wilayah studi.}

\section{Sumber: WALHI Jawa Barat 2016}

Meskipun di Jawa Barat sudah terbangun Tim Satuan Tugas (Satgas) Penegakan Hukum Lingkungan Terpadu (PHLT) namun kelembagaan ini belum memberikan kontribusi nyata dalam menegakan hukum lingkungan hingga memberikan efek jera bagi para perusak dan pencemar dan memaksa pelaku melakukan upaya pemulihan lingkungan secara nyata. Hampir dua tahun Tim Satgas PHLT bekerja, sanksi yang diberikan kepada para pelaku pencemaran dan perusak lingkungan hanya sebatas administratif berupa peringatan dan pembinaan. Sangat sedikit kasus-kasus lingkungan bisa di bawa ke meja hijau. ${ }^{30}$

30 Walhi Jabar, “Catatan Akhir Tahun...", Loc.cit. 
Kementerian LHK harus mengelola analisis mengenai dampak lingkungan untuk PLTU Batubara. Secara khusus, setiap penilaian dampak terhadap kesehatan dan lingkungan atau emisi gas rumah kaca di AMDAL juga harus diperkuat. Kementerian LHK perlu berperan kuat dalam penilaian dampak lingkungan yang berkelanjutan dari proyek PLTU Batubara dan melakukan pemeriksaan menyeluruh dari kerusakan yang disebabkan oleh PLTU ini. Setiap pembangkit listrik harus diminta untuk melaksanakan survei epidemiologi tentang dampak kesehatan terhadap penduduk setempat dan pencemaran lingkungan di dekat pembangkit listrik, kemudian mempublikasikan hasilnya secara transparan, serta menyediakan langkah-langkah jangka panjang yang jelas untuk mengurangi kerusakan. Selain itu peran serta masyarakat dalam penyusunan AMDAL tersendiri sangat penting untuk dilakukan.

Langkah besar yang harus ditempuh oleh Pemerintah Indonesia adalah membangun kesadaran dari seluruh aparat pengambil keputusan untuk menyadari akibat jangka panjang dari pemberian izin terhadap lingkungan. Tidak hanya itu, pemerintah juga harus melakukan pengawasan kepada perusahaan-perusahaan yang telah diberikan izin, karena hal tersebut merupakan kewajiban pemerintah dalam rangka melindungi dan mengelola lingkungan hidup. Langkah yang paling penting yang dapat kita ambil adalah untuk menggantikan PLTU Batubara, baik yang sudah ada maupun yang masih dalam perencanaan, dengan rencana yang jelas dan strategis untuk efisiensi energi, net metering, tersedianya sistem smart grid, dan pengembangan nasional sumber daya energi terbarukan termasuk panas bumi. Indonesia harus meningkatkan pasokan listrik dari energi terbarukan dalam rencana pembangunannya. Saat ini pemerintah menetapkan target energi terbarukan sebesar 25\% pada tahun 2025, namun target tersebut masih dilihat pesimis oleh berbagai pihak mengingat belum didukung oleh regulasi-regulasi yang diperlukan. Dengan demikian, keadaan Ini masih jauh dari pencapaian negaranegara lain yang sudah lebih awal berusaha meninggalkan batubara dan beralih pada pengembangan energi terbarukan.

\section{Penyelesaian Sengketa Lingkungan Hidup}

Penyelesaian sengketa lingkungan hidup dapat ditempuh melalui pengadilan atau di luar pengadilan berdasarkan pilihan secara sukarela para pihak yang bersengketa. Penyelesaian sengketa lingkungan merupakan bagian dari penegakan hukum lingkungan dan penegakan hukum dilaksanakan melalui berbagai jalur dengan berbagai sanksinya, seperti sanksi administrasi, sanksi perdata, serta sanksi pidana. ${ }^{31}$ Penyelesaian sengketa lingkungan hidup di dalam pengadilan meliputi gugatan perwakilan kelompok, hak gugat organisasi lingkungan, ataupun hak gugat

31 Koesnadi Hardjasoemantri, Hukum Tata Lingkungan, Edisi ke-8, Cetakan ke-19, Yogyakarta: Gadjah Mada University Press, 1998, hlm. 399. 
pemerintah. Melalui cara tersebut diharapkan selain akan menimbulkan efek jera juga akan meningkatkan kesadaran seluruh pemangku kepentingan tentang betapa pentingnya perlindungan dan pengelolaan lingkungan hidup demi kehidupan generasi masa kini dan masa depan.

Meskipun pembangunan nasional hendak menciptakan suatu kondisi sehingga setiap warga masyarakat dapat menikmati suasana serta iklim ketertiban dan kepastian hukum yang berintikan keadilan, dalam pelaksanaannya ada kemungkinan timbul benturan kepentingan, perselisihan, atau sengketa antara badan atau pejabat tata usaha negara (Pejabat TUN) dengan warga masyarakat yang dapat merugikan atau menghambat jalannya pembangunan nasional. Untuk menyelesaikan sengketa tersebut diperlukan adanya Pengadilan Tata Usaha Negara (PTUN) yang mampu menegakkan keadilan, kebenaran, dan kepastian hukum, sehingga dapat memberikan pengayoman kepada masyarakat, khususnya dalam hubungan antara badan atau Pejabat TUN dengan masyarakat.

Prinsip otonomi daerah yang telah ditegaskan dalam Undang-Undang Nomor 23 Tahun 2014 tentang Pemerintahan Daerah (UU Pemda) memberikan kewenangan kepada pemerintah daerah untuk mengambil kebijakan-kebijakan yang dianggap perlu dalam memberikan pelayanan kepada masyarakat. ${ }^{32}$ Salah satu bentuk kewenangan yang menjadi perhatian adalah kewenangan pemerintah daerah dalam menerbitkan izin yang lahir berdasarkan wewenang yang diberikan oleh undang-undang kepada pemerintah daerah. Selain dalam UU Pemda, kewenangan pemerintah daerah dalam menerbitkan izin juga diatur dalam UU PPLH. ${ }^{33}$

Proses pengawasan dalam rangka menjaga lingkungan merupakan suatu langkah yang terbaik, di mana pola penegakan hukum meliputi proses dan setiap proses harus mengacu pada ketentuian-ketentuan hukum, baik yang diatur dalam hukum pidana formal maupun pidana material. Seperti diketahui penegakan hukum lingkungan dibagi dalam 3 (tiga) tahapan pokok, yaitu: tindakan preemtif, preventif, dan represif. Tindakan preemtif adalah tindakan antisipasi yang bersifat mendeteksi secara lebih awal berbagai faktor korelasi kriminogen, yakni faktorfaktor yang memungkinkan akan terjadinya perusakan atau pencemaran lingkungan. Dengan demikian langkah preemtif merupakan upaya yang terbaik dalam upaya pencegahan pengrusakan atau pencemaran lingkungan hidup.

Dalam rangka pengendalian pencemaran lingkungan, pemerintah/ kelembagaan yang berwenang melakukan upaya akan pencegahan dan penanggulangan dampak negatif serta pemulihan kualitas memiliki peran yang sangat

32 Lihat Pasal 9 Undang-Undang Nomor 23 Tahun 2014 tentang Pemerintahan Daerah (UU Pemda) dan Lihat huruf K (tentang Pembagian Urusan Pemerintahan Bidang Lingkungan Hidup) Lampiran UU Pemda.

33 Lihat Pasal 63 ayat (2) UU PPLH. 
penting. Salah satu bentuk pengendalian pencemaran lingkungan adalah izin lingkungan yang dikeluarkan oleh badan/pejabat yang berwenang dalam bentuk Keputusan Tata Usaha negara (KTUN). ${ }^{34}$ Salah satu wewenang dari pemerintah adalah menerbitkan izin lingkungan ${ }^{35}$ yang dikeluarkan oleh badan atau pejabat yang berwenang dalam bentuk keputusan atau ketetapan yang menurut UndangUndang Nomor 51 Tahun 2009 mengenai Perubahan Kedua atas Undang-Undang Nomor 5 Tahun 1986 tentang Peradilan Tata Usaha Negara (UU PTUN) yang disebut KTUN. KTUN adalah suatu penetapan tertulis yang dikeluarkan oleh badan atau Pejabat TUN yang berisi tindakan hukum tata usaha negara yang berdasarkan peraturan perundang-undangan yang berlaku, yang bersifat konkret, individual, dan final, yang menimbulkan akibat hukum bagi seseorang atau juga badan hukum perdata. ${ }^{36}$

Dalam praktiknya terkadang penerbitan suatu KTUN dapat juga menimbulkan kerugian terhadap masyarakat karena adanya suatu unsur kesalahan atau kekeliruan. Diterbitkannya KTUN oleh badan atau pejabat berwenang yang mengandung unsur kesalahan, misalnya kesalahan menerbitkan izin lingkungan sehingga mengakibatkan perubahan bentang alam, pencemaran, dan bahkan kerusakan lingkungan, bagi pihak yang dirugikan dapat mengajukan gugatan di PTUN, agar KTUN (izin lingkungan) tersebut dibatalkan atau dinyatakan tidak sah. Gugatan oleh seseorang atau badan hukum perdata yang merasa kepentingannya dirugikan ke PTUN berisi tuntutan agar izin itu dinyatakan batal atau tidak sah oleh hakim, sehingga putusan tersebut segera menghentikan pencemaran akibat izin lingkungan yang mana tidak dibuat dengan cermat. ${ }^{37}$

Tata cara pengajuan gugatan dalam masalah lingkungan hidup oleh orang, masyarakat, dan/atau organisasi lingkungan hidup mengacu pada Hukum Acara Perdata yang berlaku. Hak masyarakat dan organisasi lingkungan hidup untuk mengajukan gugatan, masyarakat berhak mengajukan gugatan perwakilan (gugatan class action) ke pengadilan dan/atau melaporkan ke penegak hukum mengenai berbagai masalah lingkungan hidup yang merugikan perikehidupan masyarakat. Jika diketahui bahwa masyarakat menderita karena akibat pencemaran dan/atau perusakan lingkungan hidup sedemikian rupa sehingga mempengaruhi perikehidupan pokok masyarakat, maka instansi pemerintah yang bertanggung jawab di bidang lingkungan hidup dapat bertindak untuk kepentingan masyarakat.

34 Siti Sundari Rangkuti, Hukum Lingkungan dan Kebijakan Lingkungan Nasional, Surabaya: Airlangga University Press, 1996, hlm. 4.

35 Lihat Pasal 63 UU PPLH.

36 Pasal 1 angka 3 Undang-Undang Nomor 51 Tahun 2009 tentang Perubahan Kedua atas Undang-Undang Nomor 5 Tahun 1986 tentang Peradilan Tata Usaha Negara (UU PTUN).

37 Siti Sundari Rangkuti, Op.cit., hlm. 121. 
Dalam rangka pelaksanaan tanggung jawab pengelolaan lingkungan hidup sesuai dengan pola kemitraan, organisasi lingkungan hidup berhak mengajukan gugatan untuk kepentingan pelestarian fungsi lingkungan hidup. Hak mengajukan gugatan tersebut terbatas pada tuntutan untuk hak melakukan tindakan tertentu tanpa adanya tuntutan ganti rugi, kecuali biaya atau pengeluaran riil. Organisasi lingkungan hidup berhak mengajukan gugatan tersebut (gugatan legal standing) apabila memenuhi persyaratan: ${ }^{38}$

a. Berbentuk badan hukum atau yayasan;

b. Dalam anggaran dasar organisasi lingkungan hidup yang bersangkutan menyebutkan dengan tegas bahwa tujuan didirikannya organisasi tersebut adalah untuk kepentingan pelestarian fungsi lingkungan hidup; dan

c. Telah melaksanakan kegiatan sesuai dengan anggaran dasarnya.

Penegakan hukum dalam penataan ruang bertitik berat pada ketaatan terhadap Rencana Tata Ruang dan Perizinan. Dalam hal pembangunan PLTU II Cirebon, tidak sesuainya proyek pembangunan PLTU dengan RTRW Kota/Kabupaten bisa ditafsirkan sebagai tidak menaati rencana tata ruang yang telah ditetapkan. Selain itu, kondisi ini juga bisa dikategorikan sebagai pemanfaatan ruang yang tidak sesuai dengan izin peruntukkannya. Unsur-unsur ini merupakan unsur pelanggaran yang dapat dikenakan sanksi administrasi dan pidana.

Dalam putusan kasus PTUN Bandung Nomor 124/G/LH/2016/PTUN.BDG terkait Pencemaran Udaha dan Gangguan (Kebisingan, Getaran, dan Kebauan) tanggal 19 April 2017, Majelis Hakim PTUN Bandung memutus pokok perkara dengan membatalkan sekaligus memerintahkan Kepala Badan Penanaman Modal dan Perijinan Terpadu Provinsi Jawa Barat untuk mencabut Surat Keputusan Kepala Badan Penanaman Modal dan Perijinan Terpadu Provinsi Jawa Barat Nomor: 660/10/19.1.02.0/BPMPT/2016 tentang Izin Lingkungan Kegiatan Pembangunan dan Operasional PLTU Kapasitas 1×1000 MW Cirebon Kecamatan Astanajapura dan Kecamatan Mundu Daerah Kabupaten Cirebon oleh PT Cirebon Energi Prasarana tertanggal 11 Mei 2016. Setiap orang berkewajiban memelihara kelestarian fungsi lingkungan hidup serta mencegah dan menanggulangi pencemaran dan perusakan lingkungan hidup. Untuk dapat melakukan kegiatan yang kemungkinan berpengaruh terhadap lingkungan tersebut, maka seseorang atau suatu badan hukum harus memiliki izin lingkungan. ${ }^{39}$ Seharusnya pejabat yang berwenang dalam memberikan izin (dalam kasus ini BPM dan Perijinan Terpadu Provinsi Jawa Barat) memperhatikan asas kehati-hatian yang terdapat dalam UU PPLH, dengan mempertimbangkan RTRW Kabupaten Cirebon yang berlaku sebelum mengeluarkan izin lingkungan kepada usaha dan/atau kegiatan.

38 Lihat UU PPLH.

39 Bandingkan Pasal 67 UU PPLH. 


\section{Penutup}

\section{Kesimpulan}

Dari kasus rencana pembangunan PLTU II Kabupaten Cirebon ini terdapat beberapa hal yang dapat disimpulkan yaitu:

a. Pembangunan PLTU II Cirebon tidak sejalan dengan beberapa tujuan dalam SDGs pada point kesejahteran, pembangunan berkelanjutan dan pelestarian sumber daya alam. Selain itu pembangunan PLTU ini tidak sesuai RTRW yang telah ditetapkan dalam Perda dan dokumen AMDAL sebagai pendukung izin tidak melibatkan masyarakat dalam proses pembentukannya. Hal ini juga menunjukkan setidaknya terdapat tiga regulasi nasional yang berpotensi dilanggar, yaitu: UU PPLH, Peraturan Pemerintah Nomor 27 Tahun 2012 tentang Izin Lingkungan, dan Peraturan Menteri Lingkungan Hidup Nomor 16 Tahun 2012 tentang Pedoman Penyusunan Dokumen AMDAL.

b. Pengajuan gugatan dalam masalah lingkungan hidup dapat dilakukan oleh orang, masyarakat, dan/atau organisasi lingkungan hidup mengacu pada Hukum Acara Perdata yang berlaku. Masyarakat berhak mengajukan gugatan perwakilan (gugatan class action) ke pengadilan dan/atau melaporkan ke penegak hukum mengenai berbagai masalah lingkungan hidup yang merugikan perikehidupan masyarakat. Dalam rangka pelaksanaan tanggung jawab pengelolaan lingkungan hidup sesuai dengan pola kemitraan, organisasi lingkungan hidup berhak mengajukan gugatan untuk kepentingan pelestarian fungsi lingkungan hidup. Hak mengajukan gugatan tersebut terbatas pada tuntutan untuk hak melakukan tindakan tertentu tanpa adanya tuntutan ganti rugi, kecuali biaya atau pengeluaran riil. Dalam kasus izin pembangunan PLTU II Cirebon, Majelis Hakim PTUN Bandung memutus pokok perkara dengan membatalkan sekaligus memerintahkan Kepala Badan Penanaman Modal dan Perijinan Terpadu Provinsi Jawa Barat untuk mencabut Surat Keputusan Kepala Badan Penanaman Modal dan Perijinan Terpadu Provinsi Jawa Barat Nomor: 660/10/19.1.02.0/BPMPT/2016 tentang Izin Lingkungan Kegiatan Pembangunan dan Operasional PLTU Kapasitas 1x1000 MW Cirebon Kecamatan Astanajapura dan Kecamatan Mundu Daerah Kabupaten Cirebon oleh PT Cirebon Energi Prasarana tertanggal 11 Mei 2016.

\section{Saran}

Adapun yang dapat disarankan dari penelitian ini adalah :

a. Kementerian LHK perlu berperan kuat dalam penilaian dampak lingkungan yang berkelanjutan dari proyek PLTU Batubara dan melakukan pemeriksaan menyeluruh dari kerusakan yang disebabkan oleh PLTU ini. Langkah besar yang harus ditempuh oleh Pemerintah Indonesia adalah membangun kesadaran dari seluruh aparat pengambil keputusan untuk menyadari akibat jangka panjang 
dari pemberian izin terhadap lingkungan. Pemerintah juga harus melakukan pengawasan kepada perusahaan-perusahaan yang telah diberi izin, dalam rangka melindungi dan mengelola lingkungan hidup.

b. Kasus izin pembangunan PLTU II Cirebon ini memberi pelajaran bahwa seharusnya pejabat yang berwenang dalam memberikan izin (dalam kasus ini BPM dan Perijinan Terpadu) memperhatikan asas kehati-hatian yang terdapat dalam UU PPLH, dan mempertimbangkan RTRW daerahnya sebelum mengeluarkan izin lingkungan kepada usaha dan/atau kegiatan.

\section{Daftar Pustaka}

Buku

Bruce Mitchell (et.al.), Pengelolaan Sumber daya dan Lingkungan, Gadjah Mada University Press, Yogyakarta, 2000.

Daud Silalahi, Hukum Lingkungan dalam Sistem Penegakan Hukum Lingkungan Indonesia, Alumni, Bandung, 2001.

Greenpeace, Kita, Batubara \& Polusi Udara, Riset Dampak PLTU Batubara oleh Tim Peneliti Universitas Harvard - Atmospheric Chemistry Modeling Group (ACMG) dan Greenpeace Indonesia, Greenpeace Indonesia, Jakarta, 2016.

Imamulhadi, Hukum Lingkungan Alternatif: Hukum Lingkungan Adat dan Hukum Lingkungan Islam, K-Media, Yogyakarta, 2016.

Koesnadi Hardjasoemantri, Hukum Tata Lingkungan, Edisi ke-8, Cetakan ke-19, Gadjah Mada University Press, Yogyakarta, 1998.

Munadjat Danusaputro, Hukum Lingkungan, Buku 1 : Umum, Binacipta, Bandung, 1980.

Siti Sundari Rangkuti, Hukum Lingkungan dan Kebijakan Lingkungan Nasional, Airlangga University Press, Surabaya, 1996.

Sukanda Husin, Penegakan Hukum Lingkungan Indonesia, Cetakan Kedua, Sinar Grafika, Jakarta, 2009.

\section{Dokumen Lain}

M Daud Silalahi, "Perkembangan Hukum Lingkungan dalam Perkembangan Internasional dan Nasional: Ditinjau dari Perpektif Ilmu Lingkungan dalam Pembangunan Berkelanjutan", Makalah disampaikan pada Perkembangan Hukum Lingkungan Kini dan Masa Depan, Prosiding Seminar Nasional \& Kongres Pembina Hukum Lingkungan se - Indonesia, 2013.

Perserikatan Bangsa-Bangsa, "Sustainable Development Knowledge Platform", https://sustainabledevelopment.un.org/sdgs, diakses 29 Maret 2017.

Surna T. Djajadiningrat, "Pembangunan Berkelanjutan dan Berwawasan Lingkungan", Jurnal Hukum Lingkungan, Indonesian Center for Environmental Law, Tahun 1 No. 1,1994. 
United Nations Development Programme Indonesia, "Agenda Pembangunan Berkelanjutan 2030", http://www.id.undp.org/content/indonesia/ id/home/post-2015/sdg-overview/, diakses 29 Maret 2017.

Wahana Lingkungan Hidup Indonesia Jawa Barat, "Catatan Akhir Tahun Ruang dan Lingkungan Hidup Jawa Barat 2016: Krisis dan Darurat Bencana Ekologis di Jawa Barat", http://www.walhijabar.org/2016/12/29/catatan-akhir-tahun-ruangdan-lingkungan-hidup-jawa-barat-2016-krisis-dan-darurat-bencana-ekologisdi-jawa-barat/, diakses 29 Maret 2017.

\section{Dokumen Hukum}

Undang-Undang Nomor 26 Tahun 2007 tentang Penataan Ruang.

Undang-Undang Nomor 17 Tahun 2007 tentang Rencana Pembangunan Jangka Panjang Nasional 2005-2025.

Undang-Undang Nomor 32 Tahun 2009 tentang Perlindungan dan Pengelolaan Lingkungan Hidup.

Undang-Undang Nomor 51 Tahun 2009 tentang Perubahan Kedua atas UndangUndang Nomor 5 Tahun 1986 tentang Peradilan Tata Usaha Negara.

Undang-Undang Nomor 23 Tahun 2014 tentang Pemerintahan Daerah.

Peraturan Daerah Kabupaten Cirebon Nomor 17 Tahun 2011 tentang Rencana Tata Ruang Wilayah Kabupaten Cirebon Tahun 20112031.Peraturan Menteri Lingkungan Hidup Nomor 8 Tahun 2013 tentang Tata Laksana Penilaian dan Pemeriksaan Dokumen Lingkungan Hidup serta Penerbitan Izin Lingkungan.

Pokok Perkara Bekas Perkara Pengadilan Tata Usaha Negara Bandung No. 124/G/LH/2016/PTUN.BDG terkait Pencemaran Udaha dan Gangguan (Kebisingan, Getaran, dan Kebauan) yang didaftarkan di PTUN Bandung pada hari Selasa, 6 Desember 2016. 